\title{
Citra tubuh, asupan makan, dan status gizi wanita usia subur pranikah
}

\author{
Body image, dietary intake and nutritional status of premarital reproductive age women
}

Yhona Paratmanitya ${ }^{1}$, Hamam Hadi², Susetyowati ${ }^{3}$

\begin{abstract}
Background: Premarital reproductive age women are prospective mothers whose nutritional status should be monitored, because it can affect the outcome of pregnancy. Premarital period can be interpreted as pre conception period. As the wedding ceremony approaches, women's concern of their body image is increasing. Negative body image can influence their dietary intake and nutritional status. Research on the effect of pre wedding body image on women's dietary intake and nutritional status in non-western countries is still limited.

Objective: The aim of this research was to describe the relationship between body image, dietary intake and nutritional status of premarital reproductive age women in Yogyakarta city.

Method: This research was an observational research with cross-sectional design. The subjects were 157 premarital reproductive age women in Yogyakarta city who came to the office of religious affairs to register their marriage or followed the premarital advisory program. Body image was measured by Body Shape Questionnaire (BSQ-34); dietary intake was measured by SemiQuantitative Food Frequency Questionnaire (SQFFQ); and nutritional status was classified based on Body Mass Index (BMI). Data were analyzed with Chi-Square test, t-test and multiple logistic regression.

Result: Only 12,1\% of participant reported dissatisfied of their body image. Dominant factor that affect their body image was environmental influence $(O R=14,5)$. Bivariat analysis showed that there was a significant relationship between body image and nutritional status $(p<0,05$; OR=15,6), as well as dietary intake and nutritional status $(p<0,05)$. However, body image and dietary intake was not significantly associated $(p>0,05)$. Multiple logistic regression analysis showed that factors associated with nutritional status were body image, carbohydrate intake and environmental influence.

Conclusion: Body image was associated with nutritional status. However, body image does not affect dietary intake. Energy, protein, fat and carbohydrate intake were significantly associated with nutritional status.
\end{abstract}

KEY WORDS premarital reproductive age women, body image, dietary intake, nutritional status

\begin{abstract}
ABSTRAK
Latar belakang: Wanita usia subur (WUS) merupakan calon ibu yang harus diperhatikan status kesehatannya, termasuk status gizinya. Masa pranikah dapat diartikan sebagai masa prakonsepsi. Status gizi wanita prakonsepsi akan sangat berpengaruh terhadap outcome kehamilannya, sehingga status gizi wanita pranikah perlu diperhatikan. Pada masa menjelang pernikahan, perhatian wanita terhadap citra tubuhnya mengalami peningkatan. Citra tubuh yang negatif dapat berpengaruh terhadap asupan makan yang pada akhirnya dapat mempengaruhi status gizinya. Pengaruh citra tubuh terhadap asupan makan dan status gizi wanita pranikah di negara-negara non-Western belum banyak diketahui.

Tujuan: Mengetahui adanya hubungan antara citra tubuh, asupan makan, dan status gizi wanita usia subur (WUS) pranikah di Kota Yogyakarta.

Metode: Penelitian ini merupakan penelitian observasional dengan rancangan cross sectional. Penelitian dilakukan terhadap wanita usia subur (WUS) pranikah di wilayah Kotamadya Yogyakarta, yang datang ke Kantor Urusan Agama (KUA) untuk mendaftarkan pernikahannya atau untuk mengikuti penasehatan pranikah. Subjek penelitian berjumlah 157 orang. Pengukuran citra tubuh dilakukan menggunakan body shape questionnaire-34 (BSQ-34); asupan makan dengan metode semi quantitative food frequency questionnaire (SQFFQ); dan status gizi diklasifikasikan berdasarkan indeks massa tubuh (IMT). Data dianalisis dengan uji Chi Square, uji-t, dan regresi logistik ganda.

Hasil: Sejumlah 12,1\% responden diketahui mengalami ketidakpuasan terhadap citra tubuhnya. Faktor yang paling dominan mempengaruhi citra tubuh adalah pengaruh lingkungan $(O R=14,5)$. Hasil uji bivariat menunjukkan adanya hubungan antara citra tubuh dengan status gizi ( $p<0,05$; OR=15,6). Hubungan antara citra tubuh dengan asupan makan tidak bermakna secara statistik ( $p>0,05)$, sedangkan asupan makan dengan status gizi hubungannya bermakna $(p<0,05)$. Hasil analisis regresi logistik ganda menunjukkan bahwa faktor-faktor yang berhubungan dengan status gizi adalah citra tubuh, asupan karbohidrat, dan pengaruh lingkungan.

Kesimpulan: Terdapat hubungan yang bermakna antara citra tubuh dengan status gizi, namun tidak ditemukan hubungan yang bermakna antara citra tubuh dengan asupan makan.
\end{abstract}

KATA KUNCI: WUS pranikah, citra tubuh, asupan makan, status gizi

\footnotetext{
${ }^{1}$ Sekolah Tinggi IImu Kesehatan Alma Ata Yogyakarta. Jl. Ringroad Barat Daya No. 1, Tamantirto, Yogyakarta, Telp (0274) 4342288,4342270 e-mail: yhona_nitya@yahoo.com

${ }^{2}$ Magister Gizi dan Kesehatan Fakultas Kedokteran Universitas Gadjah Mada, Jl. Farmako, Sekip Utara Yogyakarta 55281, e-mail: hamam@indosat.net.id ${ }^{3}$ Program Studi Gizi Kesehatan Fakultas Kedokteran Universitas Gadjah Mada, Jl. Farmako, Sekip Utara Yogyakarta 55281, e-mail: susetyowati2000@ yahoo.com
} 


\section{PENDAHULUAN}

Wanita usia subur (WUS) didefinisikan oleh Kementerian Kesehatan RI sebagai wanita yang berada dalam periode umur antara 15-49 tahun tanpa memperhitungkan status perkawinannya. Jumlah WUS di Indonesia pada tahun 2010 sebanyak 66.326.200 jiwa. Jumlah WUS rata-rata mencapai sepertiga bagian dari total populasi suatu daerah (1).

Wanita usia subur sebagai calon ibu merupakan kelompok rawan yang harus diperhatikan status kesehatannya, terutama status gizinya. Kualitas seorang generasi penerus akan ditentukan oleh kondisi ibunya sejak sebelum hamil dan selama kehamilan. Masa pranikah dapat dikaitkan dengan masa prakonsepsi, karena setelah menikah wanita akan segera menjalani proses konsepsi. Kesehatan prakonsepsi menjadi sangat penting untuk diperhatikan termasuk status gizinya, terutama dalam upaya mempersiapkan kehamilan karena akan berkaitan erat dengan outcome kehamilan.

Sebuah penelitian kohort pada wanita di Cina menunjukkan bahwa indeks massa tubuh (IMT) wanita prakonsepsi yang tergolong sangatkurus/severely underweight ( $\leq 18,5 \mathrm{~kg} / \mathrm{m}^{2}$ ) akan berdampak pada terganggunya pertumbuhan janin saat kehamilan kelak dan berisiko untuk melahirkan bayi dengan berat badan lahir rendah (BBLR) dua kali lebih besar dibandingkan dengan wanita yang memiliki IMT prakonsepsi dengan kategori normal (19,8 $\leq$ IMT $<26$ $\left.\mathrm{kg} / \mathrm{m}^{2}\right)(2)$.

Pada masa menjelang pernikahan, perhatian terhadap citra tubuh dapat mengalami peningkatan. Citra tubuh (body image) merupakan persepsi dinamis dari tubuh seseorang yang dibentuk secara emosional dan bisa berubah seiring dengan perubahan suasana hati, pengalaman, maupun lingkungan (3).

Penelitian di Australia mengenai citra tubuh dan masa menjelang pernikahan menunjukkan bahwa dari 347 calon pengantin wanita yang menjadi sampel penelitian, lebih dari $50 \%$ sampel merencanakan untuk menurunkan berat badannya sebelum menikah, 40\% merencanakan untuk berdiit, dan sekitar $67 \%$ berencana untuk meningkatkan intensitas olahraganya (4). Sebuah penelitian di Amerika Serikat terhadap para wanita yang akan segera menikah juga menunjukkan hasil yang serupa yaitu $70 \%$ sampel berkeinginan untuk menurunkan berat badannya (5). Perhatian terhadap citra tubuh tersebut mengalami peningkatan seiring dengan semakin kuatnya pengaruh media massa dalam membentuk persepsi masyarakat mengenai keharusan untuk tampil sempurna pada saat pernikahan. Penelitian mengenai citra tubuh pada WUS pranikah di daerah non-Western masih belum banyak dilakukan.

Citra tubuh merupakan salah satu faktor yang mempengaruhi asupan makan seseorang. Perilaku diit seseorang berhubungan dengan ketidakpuasan terhadap bentuk tubuhnya dan juga keinginan untuk menjadi lebih kurus (6). Dalam sebuah penelitian di Amerika Serikat yang membandingkan persepsi tentang berat badan antara wanita dengan berat badan normal, overweight, dan obese diperoleh hasil bahwa $6 \%$ (pada sampel dengan berat badan normal), 15\% (overweight), dan 26\% (obese) menyatakan persepsi mereka mengenai berat badan yang menarik adalah berat badan yang lebih rendah dibandingkan dengan berat badan mereka saat ini. Sebesar $83 \%$ dari sampel memilih untuk melakukan diit dalam upaya menurunkan berat badannya dan beranggapan bahwa apabila mereka tidak berdiit maka berat badannya akan menjadi 2-6\% lebih besar dibandingkan dengan berat badan saat ini (7).

Berdasarkan latar belakang masalah tersebut, penulis tertarik untuk mengetahui hubungan antara citra tubuh, asupan makan, dan status gizi pada WUS pranikah di Kota Yogyakarta. Daerah perkotaan dipilih karena berdasarkan hasil penelitian diketahui bahwa perhatian terhadap bentuk tubuh dan perilaku diit wanita yang tinggal di daerah perkotaan cenderung lebih tinggi dibandingkan dengan wanita di daerah pedesaan (8).

\section{BAHAN DAN METODE}

Jenis penelitian yang digunakan adalah observasional dengan rancangan cross sectional. Penelitian dilakukan di Kotamadya Yogyakarta pada bulan Oktober 2010 - Januari 2011. Populasi penelitian adalah seluruh wanita usia subur pranikah di Kotamadya Yogyakarta. Berdasarkan hasil perhitungan besar sampel diperoleh jumlah sampel minimal yang harus dipenuhi adalah sejumlah 154 orang, namun selama penelitian diperoleh 157 subjek. Perhitungan besar sampel menggunakan rumus pengujian hipotesis untuk dua proporsi populasi (9) dengan nilai kepercayaan 95\%, kekuatan uji penelitian (power of the test) sebesar $80 \%$, proporsi wanita dengan status gizi salah di antara yang tidak puas terhadap citra tubuhnya sebesar 0,86 (10), dan proposi wanita dengan status gizi salah di antara yang puas terhadap citra tubuhnya sebesar 0,68 (10). Pengambilan sampel dilakukan dengan metode Quota Sampling.

Sampel penelitian diambil dari 5 kecamatan dengan luas wilayah terbesar di Kotamadya Yogyakarta, yaitu Kecamatan Umbulharjo, Gondokusuman, Kotagede, Tegalrejo, dan Mantrijeron melalui kegiatan pendaftaran pernikahan di Kantor Urusan Agama (KUA) yang ada di wilayah kecamatan tersebut. Luas wilayah yang besar biasanya diikuti dengan jumlah penduduk yang besar pula, sehingga akan memberikan kemungkinan yang lebih besar dalam mendapatkan sampel sesuai dengan jumlah yang ditentukan.

Kriteria inklusi yang digunakan adalah WUS yang akan segera menikah untuk pertama kali; datang ke KUA di wilayah penelitian untuk mendaftarkan pernikahannya atau untuk mengikuti penasehatan pranikah dari Badan Penasehatan, 
Pembinaan, dan Pelestarian Perkawinan (BP4); dan bersedia mengikuti penelitian dengan menandatangani form informed consent. Kriteria eksklusinya adalah WUS pranikah yang sedang menjalani diit tertentu karena penyakit. Variabel bebas dalam penelitian ini adalah citra tubuh, variabel tergantung yaitu status gizi, dan variabel antara adalah asupan makan. Selain itu, terdapat variabel yang berpotensi sebagai pengganggu yang turut diperhitungkan dalam penelitian ini yaitu umur, status sosial ekonomi, pengaruh lingkungan, dan aktivitas fisik.

Citra tubuh diukur menggunakan Body Shape Questionnaire 34 (BSQ-34) yang berisi 34 pertanyaan terkait dengan kepuasan seseorang terhadap bentuk tubuhnya, dengan skala rentang 1 (tidak pernah) sampai 6 (selalu). Skor total akan berada dalam rentang nilai 34204, di mana skor yang lebih tinggi menunjukkan adanya ketidakpuasan terhadap citra tubuh yang lebih tinggi pula. Skor BSQ kurang dari 110 dinyatakan puas, sementara skor BSQ lebih dari atau sama dengan 110 dinyatakan tidak puas (11). Kuesioner tersebut diujicobakan terlebih dahulu untuk mengetahui validitas dan reliabilitasnya. Hasil uji validitas kuesioner tersebut menunjukkan bahwa semua butir pertanyaan dinyatakan valid $(p<0,05)$. Uji reliabilitas menggunakan alpha Cronbach memberikan hasil alpha sebesar 0,978 yang berarti konsistensi internal alat ukur tersebut baik atau reliabel.

Asupan makan diukur dengan menggunakan semi quantitative food frequency questionnaire (SQFFQ), meliputi asupan energi, protein, lemak, dan karbohidrat yang dikonsumsi dalam kurun waktu 1 bulan terakhir. Hasil estimasi asupan zat gizi tersebut dibandingkan dengan nilai angka kecukupan gizi (AKG) rata-rata orang Indonesia yang disesuaikan menurut kelompok umur untuk menilai apakah asupan makan tersebut dapat mencukupi kebutuhan gizi subjek penelitian.

Pada tahap awal, SQFFQ disusun dengan memasukkan jenis-jenis makanan yang diperkirakan lazim dikonsumsi masyarakat setempat. Pada tahap ini, jumlah makanan yang masuk ke dalam daftar adalah sebanyak 172 jenis. Selanjutnya dilakukan uji coba SQFFQ tersebut terhadap 20 orang WUS yang berasal dari wilayah dengan karakteristik makanan yang serupa untuk memperoleh informasi mengenai daftar makanan yang benar-benar lazim dikonsumsi. Uji coba tersebut memberikan hasil bahwa dari 172 jenis makanan yang tercantum dalam daftar, terdapat 145 jenis makanan yang lazim dikonsumsi oleh sebagian besar responden uji coba. Oleh karena itu, yang digunakan sebagai instrumen penelitian adalah SQFFQ dengan 145 jenis makanan.

Pada saat pengambilan data asupan makan, subjek diminta untuk menjelaskan seberapa sering mengonsumsi setiap jenis makanan yang tercantum dalam kuesioner selama 1 bulan terakhir dengan kemungkinan jawaban yaitu berapa kali per hari, berapa kali per minggu, atau berapa kali per bulan. Perhitungan asupan makan subjek dilakukan dengan cara mengalikan frekuensi konsumsi yang dilaporkan oleh subjek untuk setiap jenis makanan dengan besar porsi setiap kali makan (dalam gram), kemudian hasilnya dikalikan dengan kandungan zat gizi (energi, protein, lemak, dan karbohidrat) dalam setiap jenis makanan tersebut. Langkah terakhir adalah menjumlahkan kontribusi zat-zat gizi tersebut dari semua jenis makanan yang tercantum dalam kuesioner, sehingga diperoleh rata-rata asupan makan subjek dalam 1 bulan terakhir. Pengambilan data asupan makan menggunakan bantuan food model.

Data status gizi diperoleh dengan menentukan indeks massa tubuh (IMT) yaitu dengan cara membandingkan berat badan (dalam $\mathrm{kg}$ ) dan tinggi badan (dalam $\mathrm{m}^{2}$ ). Kemudian dibedakan menjadi 3 kategori yaitu status gizi kurang (IMT<18,5), baik (IMT=18,5-22,9), dan lebih (IMT $\geq 23,0)$. Berat badan diukur menggunakan timbangan injak digital dengan ketelitian 0,1 kg. Tinggi badan diukur menggunakan microtoise dengan ketelitian $0,1 \mathrm{~cm}$. Pengukuran berat badan dan tinggi badan dilakukan di akhir proses pengambilan data.

Data umur, status sosial ekonomi, dan pengaruh lingkungan diperoleh melalui kuesioner yang dibagikan kepada subjek. Umur dikategorikan menjadi 2 yaitu kurang dari 25 tahun dan lebih dari atau sama dengan 25 tahun. Hal ini berdasarkan penelitian sebelumnya terkait citra tubuh pada wanita yang menggunakan cut off umur 25 tahun, dan hasilnya menyatakan bahwa wanita usia kurang dari 25 tahun memiliki tingkat ketidakpuasan terhadap tubuhnya yang lebih tinggi (12). Di samping itu, hasil Susenas tahun 2005 menunjukkan bahwa rata-rata usia perkawinan pada wanita Indonesia di daerah perkotaan adalah 24,6 tahun. Oleh karena itu, pada penelitian mengenai citra tubuh pada WUS pranikah ini digunakan cut off umur 25 tahun.

Status sosial ekonomi dilihat dari 3 aspek, yaitu pendidikan terakhir (tamat SD/SMP/SMA atau tamat PT), status pekerjaan (bekerja atau tidak bekerja), dan penghasilan rata-rata per bulan ( $<$ Rp 800.000,- atau $\geq R p$ $800.000,-)$. Pengaruh lingkungan dikategorikan menjadi 2 , yaitu ada pengaruh dan tidak ada pengaruh. Ada pengaruh lingkungan apabila ada orang terdekat yang obese dan atau ada saran untuk menurunkan berat badan menjelang pernikahan, dan tidak ada pengaruh lingkungan apabila tidak ada orang terdekat yang obese dan tidak ada saran untuk menurunkan berat badan menjelang pernikahan.

Data aktivitas fisik diperoleh melalui International Physical Activity Questionnaire (IPAQ). Dinyatakan dalam MET-menit/minggu, yang diperoleh dengan cara mengalikan antara level MET (metabolic equivalent) dengan jumlah menit yang digunakan untuk melakukan suatu aktivitas dalam satu hari, dikalikan jumlah hari yang digunakan untuk melakukan aktivitas tersebut dalam satu minggu (level MET 
x menit aktivitas/hari x hari/minggu) (13). Pengumpulan data dilakukan oleh peneliti dengan bantuan 5 orang enumerator yang merupakan lulusan dari S1 Gizi Kesehatan Fakultas Kedokteran UGM yang telah diberikan pengarahan sebelumnya. Data tersebut selanjutnya diuji secara statistik dengan menggunakan uji Chi Square, t-test, dan uji regresi logistik ganda.

\section{HASIL}

Tabel 1. Distribusi frekuensi karakteristik subjek penelitian

\begin{tabular}{|c|c|c|}
\hline Variabel & $\mathbf{n}$ & $\%$ \\
\hline \multicolumn{3}{|l|}{ Umur } \\
\hline$<25$ tahun & 67 & 42,7 \\
\hline$\geq 25$ tahun & 90 & 57,3 \\
\hline \multicolumn{3}{|l|}{ Pendidikan terakhir } \\
\hline Tamat SD & 3 & 1,9 \\
\hline Tamat SMP/SMA & 88 & 56,1 \\
\hline Tamat PT & 66 & 42,0 \\
\hline \multicolumn{3}{|l|}{ Status pekerjaan } \\
\hline Bekerja & 128 & 81,5 \\
\hline Tidak/belum bekerja & 29 & 18,5 \\
\hline \multicolumn{3}{|l|}{ Pekerjaan utama } \\
\hline PNS/pegawai BUMN & 9 & 7,0 \\
\hline Pegawai swasta & 76 & 59,4 \\
\hline Guru honorer/pegawai honorer & 9 & 7,0 \\
\hline Pedagang/jasa/wiraswasta & 28 & 21,9 \\
\hline Buruh/lainnya & 6 & 4,7 \\
\hline \multicolumn{3}{|l|}{ Penghasilan rata-rata per bulan } \\
\hline$<\operatorname{Rp} 800.000,-$ & 88 & 56,1 \\
\hline$\geq \operatorname{Rp} 800.000,-$ & 69 & 43,9 \\
\hline \multicolumn{3}{|l|}{ Pengaruh lingkungan } \\
\hline Ada pengaruh lingkungan & 67 & 42,7 \\
\hline Tidak ada pengaruh lingkungan & 90 & 57,3 \\
\hline \multicolumn{3}{|l|}{ Status domisili } \\
\hline Tinggal bersama orangtua & 136 & 86,6 \\
\hline Tinggal sendiri & 21 & 13,4 \\
\hline \multicolumn{3}{|l|}{ Asal KUA } \\
\hline KUA Umbulharjo & 51 & 32,5 \\
\hline KUA Gondokusuman & 31 & 19,7 \\
\hline KUA Kotagede & 20 & 12,7 \\
\hline KUA Mantrijeron & 34 & 21,7 \\
\hline KUA Tegalrejo & 21 & 13,4 \\
\hline
\end{tabular}

Keterangan: SD = sekolah dasar

SMP = sekolah menengah pertama

SMA = sekolah menengah atas

$\mathrm{PT} \quad=$ perguruan tinggi

PNS = pegawai negeri sipil

BUMN = badan usaha milik negara

$\mathrm{KUA}=$ kantor urusan agama

Subjek penelitian berjumlah 157 orang dengan persentase terbesar berasal dari KUA Kecamatan Umbulharjo yaitu sebesar 32,5\% (51 orang). Sebagian besar subjek berusia lebih dari atau sama dengan 25 tahun $(57,3 \%)$ dengan rata-rata umur sebesar 25,6 \pm 5,5 tahun. Sebanyak $56,1 \%$ subjek berpendidikan SMP/SMA dan sebagian besar sudah bekerja (81,5\%). Mayoritas subjek memiliki pekerjaan utama sebagai pegawai swasta
Tabel 2. Analisis regresi logistik ganda (variabel terikat : citra tubuh)

\begin{tabular}{lcccc}
\hline \multicolumn{1}{c}{ Variabel } & \multirow{2}{*}{ OR } & $\mathbf{p}$ & \multicolumn{2}{c}{$\mathbf{9 5 \%} \mathbf{C l}$} \\
\cline { 4 - 5 } & & & Lower & Upper \\
\hline Umur & 0,52 & 0,326 & 0,138 & 1,937 \\
$\quad<25$ tahun & & & & \\
$\quad \geq 25$ tahun & & & & \\
$\begin{array}{l}\text { Pendidikan terakhir } \\
\quad \text { Tamat PT }\end{array}$ & 3,02 & 0,084 & 0,863 & 10,540 \\
$\quad$ Tamat SD/SMP/SMA & & & & \\
$\begin{array}{l}\text { Status pekerjaan } \\
\quad \text { Bekerja }\end{array}$ & 2,42 & 0,437 & 0,260 & 22,504 \\
$\quad$ Tidak bekerja & & & & \\
$\begin{array}{l}\text { Penghasilan rata-rata per } \\
\text { bulan }\end{array}$ & 0,97 & 0,960 & 0,286 & 3,286 \\
$\quad \geq$ Rp 800.000,- & & & & \\
$\quad<$ Rp 800.000,- & & & & \\
$\begin{array}{l}\text { Pengaruh lingkungan } \\
\quad \text { Ada pengaruh lingkungan }\end{array}$ & 14,55 & 0,001 & 3,116 & 67,934 \\
$\quad$ Tidak ada & & & & \\
Log likelihood & $-43,535$ & & & \\
Pseudo R2 & 0,2484 & & \\
\hline
\end{tabular}

$(59,4 \%)$, diikuti oleh pedagang/jasa/wiraswasta $(21,9 \%)$. Sebagian besar $(56,1 \%)$ penghasilan rata-rata subjek masih kurang dari Rp 800.000,- per bulan. Berkaitan dengan ada atau tidaknya pengaruh dari lingkungan subjek dalam hal pencitraan terhadap tubuhnya, sebanyak $57,3 \%$ subjek menyatakan tidak ada pengaruh dari lingkungannya. Sementara sisanya mengaku mendapat pengaruh dari lingkungan yaitu memiliki orang terdekat yang mengalami obesitas dan atau mendapatkan saran untuk menurunkan berat badannya menjelang pernikahan. Sebagian besar subjek $(86,6 \%)$ masih tinggal bersama dengan orangtuanya (Tabel 1).

Hasil pengukuran citra tubuh menunjukkan bahwa sebagian besar subjek $(87,9 \%)$ menyatakan puas dengan bentuk tubuhnya dan hanya ditemukan $12,1 \%$ subjek yang menyatakan tidak puas. Rata-rata skor BSQ dalam penelitian ini secara keseluruhan adalah $70,3 \pm 26,4$. Ratarata skor BSQ untuk kelompok tidak puas adalah 124,2 $\pm 20,0$ dan pada kelompok puas sebesar $62,9 \pm 16,9$. Hasil analisis regresi logistik ganda menunjukkan bahwa pengaruh lingkungan merupakan faktor yang dominan dalam mempengaruhi citra tubuh $(\mathrm{OR}=14,55)$ (Tabel 2).

Hasil perbandingan antara asupan zat gizi subjek dengan AKG menunjukkan bahwa rata-rata kecukupan energi dan karbohidrat subjek masih di bawah $100 \%$ yaitu $89,1 \%( \pm 26,1)$ untuk energi dan $79,3 \%( \pm 22,9)$ untuk karbohidrat. Sementara untuk asupan protein dan lemak rata-rata kecukupannya di atas $100 \%$ yaitu $114,9 \%$ ( \pm $43,4)$ untuk protein dan $105,5 \%( \pm 40,7)$ untuk lemak. Hasil uji Chi Square antara citra tubuh dengan asupan zat gizi menunjukkan bahwa tidak ada hubungan yang bermakna antara citra tubuh dengan asupan energi, protein, lemak maupun karbohidrat. Pada kelompok subjek yang tidak 
Tabel 3. Tabulasi silang antara citra tubuh dengan status gizi

\begin{tabular}{lcccccc}
\hline \multirow{2}{*}{ Citra tubuh } & \multicolumn{2}{c}{ Status gizi } & \multirow{2}{*}{ Jumlah } & \multirow{2}{*}{$\mathbf{X}^{2}$} & \multirow{2}{*}{$\mathbf{p}$} & \multirow{2}{*}{ OR (CI) } \\
\cline { 2 - 3 } & Lebih & Kurang + Baik & & & \\
\hline Tidak puas & $14(73,7 \%)$ & $5(26,3 \%)$ & $19(100 \%)$ & \multirow{2}{*}{32,955} & \multirow{2}{*}{0,000} & 15,6 \\
Puas & $21(15,2 \%)$ & $117(84,8 \%)$ & $138(100 \%)$ & & $(4,583-59,792)$ \\
\hline
\end{tabular}

Tabel 4. Tabulasi silang antara asupan zat gizi dengan status gizi

\begin{tabular}{|c|c|c|c|c|c|c|}
\hline \multirow[b]{2}{*}{ Asupan } & \multicolumn{2}{|c|}{ Status gizi } & \multirow[b]{2}{*}{$\begin{array}{c}\text { Jumlah } \\
(\mathrm{n}, \%)\end{array}$} & \multirow[b]{2}{*}{$X^{2}$} & \multirow[b]{2}{*}{$\mathbf{p}$} & \multirow[b]{2}{*}{ OR (Cl) } \\
\hline & $\begin{array}{l}\text { Lebih } \\
(\mathrm{n}, \%)\end{array}$ & $\begin{array}{c}\text { Kurang + Baik } \\
(\mathrm{n}, \%)\end{array}$ & & & & \\
\hline \multicolumn{7}{|l|}{ Energi } \\
\hline$\geq 80 \%$ AKG & $14(14,6 \%)$ & $82(85,4 \%)$ & $96(100 \%)$ & \multirow{2}{*}{8,478} & \multirow{2}{*}{0,004} & 0,33 \\
\hline$<80 \%$ AKG & $21(34,4 \%)$ & $40(65,6 \%)$ & $61(100 \%)$ & & & $(0,138-0,755)$ \\
\hline \multicolumn{7}{|l|}{ Protein } \\
\hline$\geq 80 \%$ AKG & $21(17,2 \%)$ & $101(82,8 \%)$ & $122(100 \%)$ & \multirow[b]{2}{*}{8,152} & \multirow{2}{*}{0,004} & 0,31 \\
\hline$<80 \%$ AKG & $14(40,0 \%)$ & $21(60,0 \%)$ & $35(100 \%)$ & & & $(0,127-0,782)$ \\
\hline \multicolumn{7}{|l|}{ Lemak } \\
\hline$\geq 80 \%$ AKG & $18(16,1 \%)$ & $94(83,9 \%)$ & $122(100 \%)$ & \multirow{2}{*}{8,731} & \multirow{2}{*}{0,003} & 0,32 \\
\hline$<80 \%$ AKG & $17(37,8 \%)$ & $28(62,2 \%)$ & 45 (100\%) & & & $(0,134-0,750)$ \\
\hline \multicolumn{7}{|l|}{ Karbohidrat } \\
\hline$\geq 80 \%$ AKG & $10(13,0 \%)$ & $67(87,0 \%)$ & 77 (100\%) & \multirow{2}{*}{7,554} & \multirow{2}{*}{0,006} & 0,33 \\
\hline$<80 \%$ AKG & $25(31,3 \%)$ & $55(68,8 \%)$ & $80(100 \%)$ & & & $(0,130-0,787)$ \\
\hline
\end{tabular}

Keterangan: $A K G$ = angka kecukupan gizi

puas terhadap citra tubuhnya, sebagian besar berada pada kategori asupan lebih dari atau sama dengan 80\% AKG untuk asupan energi, protein, dan lemak, sedangkan untuk asupan karbohidrat sebagian besar berada pada kategori asupan kurang dari $80 \%$ AKG.

Hasil $t$-test juga menunjukkan bahwa tidak terdapat perbedaan rata-rata asupan energi, protein, lemak, maupun karbohidrat yang signifikan antara kelompok subjek yang puas dan tidak puas terhadap citra tubuhnya. Namun ada kecenderungan bahwa subjek yang tidak puas memiliki rata-rata asupan zat gizi yang lebih rendah dibandingkan dengan subjek yang puas, meskipun perbedaan tersebut tidak bermakna.

Hasil penelitian menunjukkan bahwa sebagian besar subjek memiliki status gizi baik (54,8\%) dengan rata-rata IMT subjek secara keseluruhan adalah 21,1 ( \pm $3,8)$. Sebanyak $22,9 \%$ subjek memiliki status gizi kurang dan $22,3 \%$ subjek berstatus gizi lebih.

Hasil uji statistik menunjukkan bahwa terdapat hubungan yang signifikan antara citra tubuh dengan status gizi subjek $(p=0,000)$. Odds Ratio (OR) sebesar 15,6 menunjukkan bahwa subjek yang tidak puas terhadap citra tubuhnya memiliki kemungkinan 15,6 kali lebih besar untuk mengalami status gizi lebih dibandingkan dengan subjek yang puas terhadap citra tubuhnya (Tabel 3 ).

Data dalam Tabel 3 menunjukkan bahwa sebagian besar subjek yang tidak puas memiliki status gizi lebih. Hasil uji t untuk melihat perbedaan rata-rata IMT antara subjek yang puas dan tidak puas juga menunjukkan perbedaan yang signifikan $(p<0,05)$. Rata-rata indeks massa tubuh pada kelompok subjek yang puas adalah 20,3 $\pm 3,1 \mathrm{~kg} / \mathrm{m}^{2}$ sementara pada kelompok subjek yang tidak puas adalah $26,4 \pm 4,1 \mathrm{~kg} / \mathrm{m}^{2}$. Pada penelitian ini status gizi lebih disendirikan sedangkan status gizi kurang dan baik digabung karena ketidakpuasan terhadap citra tubuh pada umumnya terkait dengan status gizi lebih.

Hasil uji Chi Square menunjukkan bahwa asupan makan yang meliputi asupan energi, protein, lemak, dan karbohidrat memiliki hubungan yang signifikan dengan status gizi dengan nilai OR berturut-turut adalah 0,33; 0,31; 0,32 ; dan 0,33 . Nilai OR yang kurang dari 1 memberikan arti bahwa subjek dengan asupan makan yang lebih tinggi malah memiliki risiko yang lebih rendah untuk mengalami gizi lebih (Tabel 4).

Hasil analisis perbedaan rata-rata asupan antara kelompok status gizi kurang dan baik dengan kelompok status gizi lebih menunjukkan bahwa rata-rata asupan zat gizi subjek yang memiliki status gizi lebih cenderung lebih rendah dibandingkan dengan rata-rata asupan zat gizi subjek yang memiliki status gizi kurang dan baik. Hasil uji statistik menunjukkan adanya perbedaan rata-rata asupan energi, lemak, dan karbohidrat yang signifikan antara kelompok status gizi kurang dan baik dengan kelompok status gizi lebih $(p<0,05)$. Analisis multivariat menggunakan regresi logistik ganda dilakukan untuk mengetahui faktor apa saja yang berhubungan dengan status gizi. Berdasarkan hasil uji bivariat yang telah dipaparkan sebelumnya, variabel yang terkait dengan status gizi dan memiliki tingkat kemaknaan $(p<0,25)$ adalah citra tubuh, asupan energi, asupan protein, asupan lemak, asupan karbohidrat, dan pengaruh lingkungan. 
Tabel 5. Analisis regresi logistik (variabel terikat : status gizi)

\begin{tabular}{|c|c|c|c|c|c|c|c|c|}
\hline \multirow{2}{*}{ Variabel } & \multicolumn{2}{|c|}{ Model 1} & \multicolumn{2}{|c|}{ Model 2} & \multicolumn{2}{|c|}{ Model 3} & \multicolumn{2}{|c|}{ Model 4} \\
\hline & OR & $\mathbf{p}$ & OR & $\mathbf{p}$ & OR & $\mathbf{p}$ & OR & $\mathbf{p}$ \\
\hline Citra tubuh & & & & & & & & \\
\hline $\begin{array}{l}\text { Tidak puas } \\
\text { Puas }\end{array}$ & $\begin{array}{c}10,19 \\
(2,83-36,68)\end{array}$ & 0,000 & $\begin{array}{c}10,39 \\
(2,88-37,41)\end{array}$ & 0,000 & $\begin{array}{c}10,10 \\
(2,80-36,41)\end{array}$ & 0,000 & $\begin{array}{c}9,35 \\
(2,64-33,05)\end{array}$ & 0,001 \\
\hline Asupan energi & & & & & & & & \\
\hline $\begin{array}{l}\geq 80 \% \text { AKG } \\
<80 \% \text { AKG }\end{array}$ & $\begin{array}{c}0,62 \\
(0,11-3,70)\end{array}$ & 0,603 & $\begin{array}{c}0,54 \\
(0,10-2,92)\end{array}$ & 0,475 & - & - & - & - \\
\hline Asupan protein & & & & & & & & \\
\hline $\begin{array}{l}\geq 80 \% \text { AKG } \\
<80 \% \text { AKG }\end{array}$ & $\begin{array}{c}0,66 \\
(0,16-2,74)\end{array}$ & 0,566 & $\begin{array}{c}0,55 \\
(0,16-1,92)\end{array}$ & 0,351 & $\begin{array}{c}0,45 \\
(0,15-1,37)\end{array}$ & 0,159 & - & - \\
\hline Asupan lemak & & & & & & & & \\
\hline $\begin{array}{l}\geq 80 \% \text { AKG } \\
<80 \% \text { AKG }\end{array}$ & $\begin{array}{c}0,71 \\
(0,18-2,86)\end{array}$ & 0,629 & - & - & - & - & - & - \\
\hline Asupan karbohidrat & & & & & & & & \\
\hline $\begin{array}{l}\geq 80 \% \text { AKG } \\
<80 \% \text { AKG }\end{array}$ & $\begin{array}{c}0,50 \\
(0,10-2,40)\end{array}$ & 0,387 & $\begin{array}{c}0,52 \\
(0,11-2,47)\end{array}$ & 0,407 & $\begin{array}{c}0,35 \\
(0,12-1,05)\end{array}$ & 0,061 & $\begin{array}{c}0,25 \\
(0,09-0,67)\end{array}$ & 0,006 \\
\hline Pengaruh lingkungan & & & & & & & & \\
\hline $\begin{array}{l}\text { Ada pengaruh lingkungan } \\
\text { Tidak ada }\end{array}$ & $\begin{array}{c}5,74 \\
(2,09-15,80)\end{array}$ & 0,001 & $\begin{array}{c}5,78 \\
(2,11-15,88)\end{array}$ & 0,001 & $\begin{array}{c}5,76 \\
(2,10-15,76)\end{array}$ & 0,001 & $\begin{array}{c}6,06 \\
(2,23-16,47)\end{array}$ & 0,000 \\
\hline Log likelihood & $-57,558$ & & $-57,675$ & & $-57,937$ & & $-58,931$ & \\
\hline $\mathrm{R}^{2}$ & 0,3091 & & 0,3077 & & 0,3045 & & 0,2926 & \\
\hline
\end{tabular}

Keterangan: $\mathrm{AKG}=$ angka kecukupan gizi

Hasil analisis regresi logistik ganda (Tabel 5) menunjukkan bahwa faktor-faktor yang memiliki hubungan siginifikan dengan status gizi adalah citra tubuh, asupan karbohidrat, dan pengaruh lingkungan. Variabel citra tubuh memiliki hubungan yang paling kuat dengan status gizi, ditunjukkan oleh nilai $\mathrm{OR}$ yang paling besar pada setiap modelnya.

\section{BAHASAN}

Berdasarkan hasil penelitian, dari 157 WUS pranikah yang menjadi subjek penelitian hanya 19 orang $(12,1 \%)$ yang mengalami ketidakpuasan terhadap citra tubuhnya. $\mathrm{Hal}$ ini berbeda dengan hasil penelitian di Australia yang menunjukkan persentase ketidakpuasan yang lebih tinggi, yaitu dari 347 calon pengantin di antaranya merencanakan untuk menurunkan berat badan sebelum pernikahan (50\%), berdiit $(40 \%)$, dan meningkatkan intensitas olahraganya (67\%) (4). Perilaku-perilaku tersebut menunjukkan adanya ketidakpuasan calon pengantin wanita terhadap bentuk tubuhnya menjelang pernikahan.

Perbedaan hasil penelitian ini dapat disebabkan oleh adanya perbedaan karakteristik lingkungan sekitar subjek penelitian yang meliputi faktor budaya ataupun sosial ekonomi, selain itu tentunya karena ada perbedaan parameter pengukuran ketidakpuasan terhadap citra tubuh. Pada kebudayaan barat (western culture) tekanan untuk memiliki tubuh langsing menjadi jauh lebih besar dibandingkan dengan kebudayaan timur, karena tubuh yang langsing merupakan simbol kesuksesan dan lebih dapat diterima dalam pergaulan sosial (14). Masyarakat Kota Yogyakarta khususnya WUS pranikah yang menjadi subjek penelitian ini, meskipun mulai terpapar oleh budaya-budaya barat namun sepertinya belum terlalu memperhatikan pencitraan tubuh sampai pada tahap tersebut, sehingga persentase ketidakpuasan terhadap citra tubuhnya masih rendah.

Hasil analisis multivariat menunjukkan bahwa faktor yang paling dominan mempengaruhi citra tubuh adalah faktor pengaruh lingkungan. Wanita usia subur pranikah yang mendapatkan pengaruh dari lingkungannya (ada orang terdekat yang mengalami obesitas dan atau ada saran/komentar untuk menurunkan berat badannya menjelang pernikahan) berisiko 14,55 kali lebih besar untuk menjadi tidak puas terhadap citra tubuhnya dibandingkan dengan wanita yang tidak mendapatkan pengaruh dari lingkungannya.

Hal ini sejalan dengan penelitian sebelumnya di Yordania yang menyatakan bahwa adanya komentar negatif dari orang sekitar terkait dengan berat badan dapat meningkatkan risiko ketidakpuasan terhadap citra tubuh hampir sebesar 2 kalinya (14). Penelitian lain di Kanada juga menyatakan bahwa citra tubuh dapat dipengaruhi oleh beberapa faktor eksternal, seperti pengaruh media massa, pengaruh dari pasangan, pengaruh dari teman, ataupun pengaruh dari tenaga kesehatan (15).

Pencitraan seseorang terhadap bentuk tubuhnya dapat mempengaruhi asupan makannya. Suatu penelitian di Kanada memberikan hasil bahwa para wanita yang melakukan diit dalam jangka waktu lama (chronic diiters) apabila dibandingkan dengan wanita yang tidak berdiit, terbukti memiliki perhatian yang lebih terhadap penampilannya, lebih tidak puas terhadap bentuk 
tubuhnya, dan merasa memiliki berat badan yang lebih besar dibandingkan berat badan aktualnya (16). Hal ini menunjukkan bahwa persepsi yang negatif terhadap tubuhnya dapat berpengaruh pada perilaku makannya, meskipun sebenarnya memiliki berat badan yang normal.

Penelitian lain di Kanada juga mengemukakan hal yang serupa. Lebih dari 25\% respondennya yang melakukan diit sebenarnya telah memiliki berat badan yang tergolong normal (17). Penelitian tersebut juga menunjukkan bahwa perhatian terhadap berat badan, perilaku diit, dan kebiasaan untuk melewatkan salah satu waktu makan (meal skipping) berhubungan dengan kualitas makanan yang lebih rendah. Kualitas makanan yang dikonsumsi tersebut dinilai menggunakan healthy eating index $(\mathrm{HEI})$ yang memiliki rentang skor 0 - 100, di mana semakin tinggi skor HEI maka kualitas makanannya semakin baik atau semakin mendekati rekomendasi asupan makan yang dianjurkan. Apabila skor HEI kurang dari atau sama dengan 50 dikategorikan sebagai buruk (poor), 50-80 dikategorikan membutuhkan perbaikan (needs improvement), dan lebih dari 80 dikategorikan baik (good). Kelompok responden yang sangat memperhatikan berat badan dan melakukan diit memiliki rata-rata skor $\mathrm{HEI}$ yang paling rendah yaitu 66 .

Pada penelitian ini, hubungan antara citra tubuh dengan asupan makan yang meliputi asupan energi, protein, lemak, dan karbohidrat tidak terbukti bermakna meskipun ada kecenderungan bahwa kelompok yang tidak puas memiliki rata-rata asupan makan yang lebih rendah dibandingkan dengan kelompok yang puas. Hal ini serupa dengan hasil penelitian di Yogyakarta yang menunjukkan tidak adanya hubungan yang signifikan antara citra tubuh dengan asupan energi respondennya (18). Ketidakpuasan subjek terhadap citra tubuh ternyata belum memberikan pengaruh yang bermakna terhadap perubahan asupan makannya. Hal ini disebabkan sebagian besar subjek masih tinggal bersama dengan orang tua $(86,6 \%)$, sehingga peran orang tua sebagai penyedia makanan di rumah masih cukup besar dan mengakibatkan kuantitas asupan makannya pun hampir seragam.

Meskipun demikian pada kelompok subjek yang tidak puas, sebagian besar mengonsumsi karbohidrat kurang dari $80 \%$ AKG. Hal ini diduga terkait dengan adanya upaya pengurangan asupan karbohidrat oleh responden, yaitu dengan mengurangi makan nasi untuk menurunkan berat badannya. Diit rendah karbohidrat menjadi salah satu jenis diit populer untuk menurunkan berat badan. Hasil penelitian di Swiss pun membuktikan bahwa diit rendah karbohidrat sama efektifnya dengan diit rendah lemak untuk menurunkan berat badan dalam jangka waktu 1 tahun (19).

Hasil uji statistik menunjukkan adanya hubungan yang signifikan antara citra tubuh dengan status gizi. Nilai OR sebesar 15,6 menunjukkan bahwa subjek yang mengalami ketidakpuasan terhadap citra tubuh memiliki kemungkinan 15,6 kali lebih besar untuk memiliki status gizi lebih, atau dapat juga dikatakan bahwa subjek dengan status gizi lebih berisiko 15,6 kali lebih besar untuk menjadi tidak puas terhadap citra tubuhnya. Penelitian ini belum dapat menentukan faktor sebab dan akibat secara jelas, karena variabel-variabelnya diukur pada satu waktu yang hampir bersamaan, sehingga belum diketahui apakah citra tubuh yang mempengaruhi status gizi atau status gizi yang berpengaruh terhadap citra tubuhnya. Namun hasil penelitian ini secara logika lebih menunjukkan bahwa status gizi lebih merupakan salah satu faktor risiko terjadinya ketidakpuasan terhadap citra tubuh.

Perasaan tidak puas terhadap citra tubuh selanjutnya dapat berpengaruh terhadap status gizinya, misalnya dengan melakukan diit untuk menurunkan berat badannya. Penelitian sebelumnya di Italia telah membuktikan bahwa perilaku diit seseorang berhubungan dengan ketidakpuasan terhadap bentuk tubuhnya dan juga keinginan untuk menjadi lebih kurus (6). Namun pada penelitian ini, pengaruh citra tubuh dalam perubahan berat badan belum dapat digambarkan dengan jelas.

Hubungan yang signifikan antara citra tubuh dengan status gizi ini sejalan dengan hasil penelitian sebelumnya yang menyatakan bahwa orang dengan IMT yang lebih tinggi cenderung lebih tidak puas terhadap citra tubuhnya $(18,20)$. Adanya perbedaan rata-rata IMT antara kelompok puas dengan kelompok tidak puas yang signifikan juga mendukung hal tersebut. Rata-rata IMT pada kelompok tidak puas cenderung lebih tinggi dibandingkan dengan rata-rata IMT pada kelompok puas.

Asupan makan merupakan faktor yang berpengaruh langsung secara linier dalam menentukan status gizi seseorang. Penelitian sebelumnya di Amerika Serikat membuktikan bahwa peningkatan IMT responden dalam masa satu tahun pengamatan terjadi lebih besar pada responden yang memiliki rata-rata asupan kalori lebih tinggi (21). Penelitian lain juga mengemukakan bahwa seseorang dengan asupan energi tidak cukup memiliki risiko 3,2 kali lebih besar untuk mengalami kekurangan gizi dibandingkan dengan responden dengan asupan energi yang cukup (22).

Pada penelitian ini, asupan makan yang meliputi asupan energi, protein, lemak, dan karbohidrat memiliki hubungan yang signifikan dengan status gizi. Nilai OR untuk masing-masing zat gizi tersebut menunjukkan angka kurang dari 1 yang berarti ada hubungan yang berkebalikan antara asupan zat gizi dengan status gizi. Subjek dengan asupan gizi yang lebih tinggi malah memiliki kemungkinan lebih rendah untuk mengalami gizi lebih. Perbedaan hasil penelitian ini diduga dipengaruhi oleh faktor pencitraan tubuh yang dirasakan oleh subjek. Subjek dengan status gizi lebih akan cenderung tidak puas dengan citra tubuhnya sehingga akan mengurangi asupan makannya dengan tujuan untuk menurunkan berat badannya menjadi 
normal. Hasil penelitian di Amerika Serikat menunjukkan bahwa keinginan orang obese untuk menurunkan berat badannya lebih besar dibandingkan dengan orang yang overweight atau normal (7).

Dugaan adanya pengaruh dari citra tubuh terhadap asupan makan yang menyebabkan terciptanya hubungan yang berkebalikan antara asupan makan dengan status gizi. Hal ini didukung oleh data yang menunjukkan bahwa pada kelompok subjek yang tidak puas, rata-rata asupan makannya lebih rendah dibandingkan dengan kelompok subjek yang puas. Responden yang tidak puas terhadap citra tubuhnya cenderung memiliki status gizi lebih, sehingga pada kelompok subjek dengan status gizi lebih rata-rata asupan makannya malah cenderung lebih rendah. Pengambilan data mengenai citra tubuh dan asupan makan memiliki kerangka waktu (time frame) yang sama yaitu dalam 1 bulan terakhir, sehingga pengaruh faktor pencitraan tubuh terhadap asupan makan dapat terjadi.

Hasil analisis perbedaan rata-rata asupan zat gizi antara kelompok status gizi kurang dan baik dengan kelompok status gizi lebih juga mendukung hal tersebut. Rata-rata asupan zat gizi subjek yang memiliki status gizi lebih cenderung lebih rendah dibandingkan dengan rata-rata asupan zat gizi subjek yang memiliki status gizi kurang dan baik. Hal ini dapat dikaitkan dengan faktor pencitraan tubuh, yaitu subjek dengan status gizi lebih akan merasa tidak puas dengan bentuk tubuhnya, sehingga salah satu upaya untuk memiliki status gizi normal adalah dengan mengurangi asupan makannya. Hasil uji statistik menunjukkan adanya perbedaan rata-rata asupan energi, lemak, dan karbohidrat yang signifikan antara kelompok status gizi kurang dan baik dengan kelompok status gizi lebih $(p<0,05)$.

Pengambilan data asupan makan dan status gizi yang dilakukan pada satu waktu tertentu juga dapat mempengaruhi hasil penelitian ini, sehingga tidak dapat ditentukan faktor sebab dan akibat secara jelas. Secara logika, hasil penelitian ini lebih menunjukkan bahwa status gizi merupakan salah satu faktor yang mempengaruhi asupan makan responden. Pengaruh asupan makan terhadap status gizi belum dapat terlihat jelas dalam penelitian ini.

Berdasarkan hasil analisis regresi logistik terhadap beberapa variabel yang diduga berhubungan dengan status gizi, pada model 4 diketahui bahwa faktor-faktor yang memiliki hubungan signifikan dengan status gizi dalam penelitian ini adalah citra tubuh, asupan karbohidrat, dan pengaruh lingkungan. Dari keempat model yang ditampilkan, meskipun nilai $R^{2}$ terbesar ditunjukkan pada model 1 yaitu 0,3091 , namun perbedaannya dengan model 4 tidak terlalu signifikan atau dapat dikatakan bahwa dengan adanya variabel asupan makan, perubahan nilai $\mathrm{R}^{2}$-nya tidak terlalu besar sehingga tidak menjadikan model lebih baik. Oleh karena itu dalam penelitian ini, model 4 dipilih untuk menjelaskan faktor-faktor yang terkait dengan status gizi. Hasil analisis multivariat tersebut juga menunjukkan bahwa variabel yang paling dominan berhubungan dengan status gizi adalah citra tubuh, yang dibuktikan dengan nilai OR yang paling besar.

Adanya hubungan antara citra tubuh dan status gizi ini juga dikemukakan oleh penelitian-penelitian sebelumnya $(14,18)$. Seseorang yang memiliki status gizi lebih berisiko lebih besar untuk mengalami ketidakpuasan terhadap bentuk tubuhnya. Bahkan pada individu dengan status gizi normal pun ada yang tidak puas terhadap citra tubuhnya dan masih berkeinginan untuk menurunkan berat badannya melalui pembatasan asupan makan $(16,17)$. Hal ini tentunya perlu mendapat perhatian yang lebih, terutama pada wanita masa prakonsepsi, karena pembatasan asupan makan yang terlalu ketat dan berlangsung dalam jangka waktu yang lama dapat mempengaruhi status gizinya. Telah banyak penelitian yang membuktikan bahwa status gizi ibu sebelum hamil dapat mempengaruhi outcome kehamilannya $(2,23,24)$.

\section{KESIMPULAN DAN SARAN}

Terdapat hubungan yang signifikan antara citra tubuh dengan status gizi wanita usia subur pranikah di Kota Yogyakarta. Wanita dengan gizi lebih cenderung lebih tidak puas terhadap citra tubuhnya. Namun tidak ditemukan hubungan yang signifikan antara citra tubuh dengan asupan makan wanita usia subur pranikah di Kota Yogyakarta. Asupan energi, protein, lemak, dan karbohidrat memiliki hubungan yang signifikan dengan status gizi wanita usia subur pranikah di Kota Yogyakarta. Wanita dengan gizi lebih, rata-rata asupan makanannya cenderung lebih rendah.

Berdasarkan kesimpulan tersebut maka disarankan bahwa informasi mengenai kesehatan reproduksi, termasuk masalah gizi prakonsepsi perlu dipertimbangkan untuk diberikan kepada para calon pengantin dalam satu paket informasi yang disampaikan oleh Badan Penasehatan, Pembinaan, dan Pelestarian Perkawinan (BP4). Pada penelitian selanjutnya, untuk mengetahui pengaruh citra tubuh terhadap status gizi secara jelas, perlu dilakukan penelitian kohort agar dapat ditentukan faktor sebab dan akibatnya.

\section{RUJUKAN}

1. Keputusan Sekretaris Jenderal Kementerian Kesehatan Nomor HK.03.01/VI/432/2010 tentang Data Sasaran Program Kementerian Kesehatan Tahun 2010.

2. Ronnenberg $A G$, Wang $X$, Xing $H$, Chen $C$, Chen D, Guang W, Guang A, Wang L, Ryan L, Xu X. Low preconception body mass index is associated with birth outcome in a prospective cohort of Chinese women. $\mathrm{J}$ Nutr 2003;133:3449-55.

3. Croll J. Body image and adolescents. In: Guidelines for adolescent nutrition services [serial online] 2005 
[cited 2010 Feb 21]. Available from: http://www.epi. umm.edu/let/pubs.

4. Prichard I, Tiggemann M. An examination of pre-wedding body image concerns in brides and bridesmaids. Body Image 2008;5:395-8.

5. Neighbors LA, Sobal J. Weight and weddings: women's weight ideals and weight management behaviors for their wedding day. Appetite 2007;50:550-4.

6. Boschi V, Siervo M, D'Orsi P, Margiotta N, Trapanese E, Basile F, Nasti G, Papa A, Bellini O, Falconi, C. Body composition, eating behavior, food-body concerns and eating disorders in adolescent girls. Ann Nutr Metab 2003;47(6):284-93.

7. Malinauskas BM, Raedeke TD, Aeby VG, Smith JL, Dallas MB. Dieting pratices, weight perceptions, and body composition: a comparison of normal weight, overweight and obese college females. Nutr J 2006;5:11.

8. Omar Dev RD, Permal V, Fauzee MSO. Rural urban differences in body image perception, body mass index and dieting behaviour among Malay adolescent Malaysian schoolgirls. Eur J Sci Res 2009;34(1):6982.

9. Lemeshow S, Hosmer DWJr, Klar J, Lwanga SK. Besaran sampel dalam penelitian kesehatan. Pramono D (Alih bahasa). Yogyakarta: Gadjah Mada University Press; 1997.

10. Faber M, Kruger S. Dietary intake, perception regarding body weight, and attitudes toward weight control of normal weight, overweight, and obese Black females in a rural village in South Africa. Ethn Dis 2005;15(2):238-45.

11. Hansen KSW. Body shape dissatisfaction: patterns of concern among subgroups of college freshmen women [Thesis]. Amerika Serikat: Department of Counseling Psychology and Special Education Brigham Young University; 2008.

12. Sivert SS, Sinanovic O. Body dissatisfaction - is age a factor?. Facta Universitatis. Series: Philosophy, Sociology, Psychology and History 2008;7(1):55-61.

13. International Physical Activity Questionnaire. Guidelines for data processing and analysis of the international physical activity questionnaire (IPAQ)-short and long forms [serial online] 2005 [cited 2010 Jun 28]. Available from: http://www.ipaq.ki.se/scoring.htm.

14. Mousa YT, Mashal RH, Al-Domi HA, Jibril MA. Body image dissatisfaction among adolescent schoolgirls in Jordan. Body Image 2010;7(1):46-50.

15. Paquette MC, Raine K. Sociocultural context of women's body image. Soc Sci Med 2004;59:1047-58.

16. Gingras J, Fitzpatrick J, McCargar L. Body image of chronic diiters: lowered appearance evaluation and body satisfaction. J Am Diet Assoc 2004;104:1589-92.

17. Woodruff SJ, Hanning RM, Lambraki I, Storey KE, McCargar L. Healthy eating index-C is compromised among adolescents with body weight concerns, weight loss diiting, and meal skipping. Body Image 2008;5(4):404-8.

18. Tarigan $\mathrm{N}$, Hadi $\mathrm{H}$, Julia M. Hubungan citra tubuh dengan status obesitas, aktivitas fisik, dan asupan energi remaja SLTP di Kota Yogyakarta dan Kabupaten Bantul. Jurnal Gizi Klinik Indonesia 2005;1(3):130-6.

19. Nordmann AJ, Nordmann A, Briel M, Keller U, Yancy WS, Brehm BJ, Bucher HC. Effects of low-carbohydrate vs low-fat diits on weight loss and cardiovascular risk factors. A meta-analysis of randomized controlled trials. Arch Intern Med 2006;166:285-93.

20. Gittelsohn J, Harris SB, Thorne-Lyman AL, Hanley AJG, Barnie A, Zinman B. Body image concepts differ by age and sex in an Ojibway-Cree Community in Canada. J Nutr 1996;126(12):2990-3000.

21. Berkey CS, Rockett HRH, Field AE, Gillman MW, Fraizer AL, Camargo JrCA, Colditz GA. Activity, diitary intake, and weight changes in a longitudinal study of preadolescent and adolescent boys and girls. Pediatrics 2000;105(4):1-9.

22. Dwiyanti D, Hadi H, Susetyowati. Pengaruh asupan makanan terhadap kejadian malnutrisi di rumah sakit. Jurnal Gizi Klinik Indonesia 2004;1(1):1-7.

23. Neggers Y, Goldenberg RL. Some thoughts on body mass index, micronutrient intakes and pregnancy outcome. J Nutr 2003;133:1737S-40.

24. Kristensen J, Vestergaard M, Wisborg K, Kesmodel $U$, Secher NJ. Pre-pregnancy weight and the risk of stillbirth and neonatal death. Int J Obstet Gynecol 2005;112:403-8. 